\title{
O teatro cego e a articulação de signos não visuais na condução da fábula
}

\author{
Victor H. C. Sousa*, Gina M. M. Aguilar, Rodrigo S. O. Castro
}

\section{Resumo}

Este projeto propõe-se a uma pesquisa teórico-prática sobre o teatro cego - linguagem que coloca atores e espectadores em uma sala mergulhada na mais completa escuridão -, em seus aspectos cênicos e extra-cênicos, com atenção à rede de signos não visuais que leva à condução da fábula em um espetáculo que se vale da forma.

\section{Palavras-chave:}

Teatro cego, signo cênico, acessibilidade cultural

\section{Introdução}

Ao identificar na anulação da visão um elemento de potencialização poética da cena, o teatro cego abre caminho para as pessoas com deficiência visual, que passam a compor no elenco e na plateia das peças. Assim, é uma possibilidade de arte inclusiva e sensorial, algo que vem ganhando cada vez mais terreno nos últimos anos, apesar de ainda pouco falado na academia. Essa pesquisa vem no intuito de contribuir para a mudança desse quadro. Ela é composta por duas etapas, uma teórica e outra prática: o estudo da linguagem em seus aspectos poéticos, estéticos, sociais e políticos, bem como das articulações sígnicas utilizadas em uma montagem do grupo paulistano de teatro cego, e a exploração prática de possibilidades de signos cênicos não visuais por meio de um grupo de estudos.

\section{Resultados e Discussão}

Numa sociedade tão predominantemente visual como a nossa, o teatro cego ajuda a abrir caminho para outras formas de perceber e conhecer a realidade. A produtora cultural paulistana Caleidoscópio Comunicação \& Cultura, que trabalha com a linguagem, afirma que tem dois objetivos com o projeto: abrir espaço no teatro para as pessoas com deficiência visual, e mostrar aos videntes, isto é, às pessoas que veem, que é possível enxergar sem o uso da visão. É o estímulo da "intravisão", como sugere o carioca Teatro dos Sentidos, em que a incitação dos outros sentidos gera imagens visuais na imaginação de cada um. Isso coloca a linguagem do teatro cego no meio do caminho entre a literatura e o cinema, pois ao mesmo tempo em que é profundamente sugestiva, também é fortemente ilusionista.

E como isso se dá? Através de recursos olfativos, táteis, gustativos, e sobretudo acústicos. A cena é construída principalmente por meio de sons. É a "cenografia sonora", como coloca José Menchaca, diretor que trabalha com o teatro cego em Buenos Aires. Os sons, signos em geral temporais, determinam o espaço cênico. Essa escolha traz a necessidade de um cuidado ainda maior com a escrita cênica: todo equívoco pode gerar enormes problemas de leitura. Mergulhar o teatro, o "miradouro" dos gregos, no escuro - uma escolha potente, mas arriscada. Que fábula pede por essa linguagem? Tirar os elementos visuais de uma arte que tanto se vale deles não a limita demais? Isso é mesmo teatro?

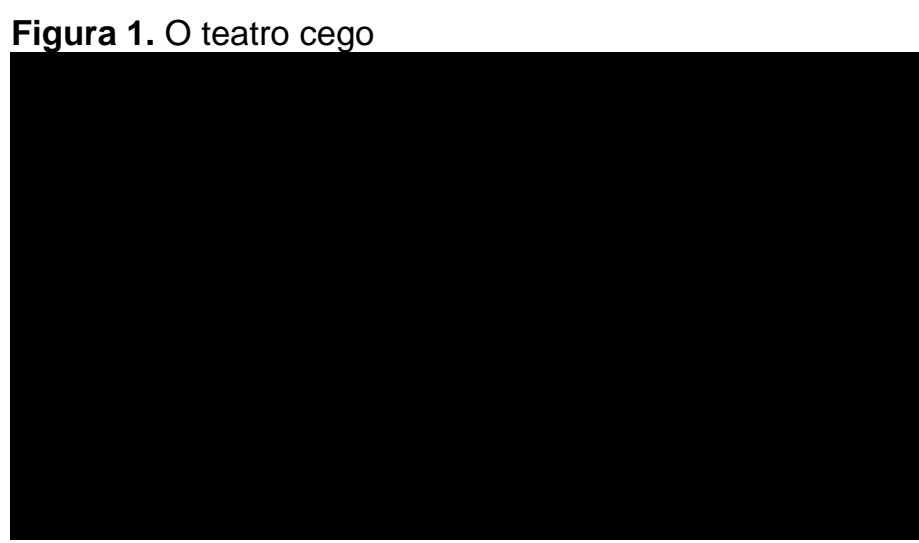

\section{Conclusões}

A pesquisa levantou muitas perguntas, mas não tão numerosas foram as respostas, o que mostra que sobre o tema do teatro cego ainda há muito a se explorar.

Mas uma das mais valiosas conclusões a que se chegou é a respeito da inegável teatralidade da linguagem. $O$ teatro não tem leis permanentes ou regras definitivas. "A corrente elétrica”, como coloca Honzl (1978), da ação dramática está sempre trocando o elemento cênico em foco. Assim, "descobrimos surpresos que o espaço cênico não é necessariamente um espaço, mas que o som pode igualmente representar um palco, que a música pode ser o evento, o cenário é a mensagem, etc."

\section{Agradecimentos}

Agradeço à FAPESP, aos meus orientadores e aos demais professores do Departamento de Artes Cênicas da UNICAMP, aos grupos de teatro cego e à minha mãe, sempre tão companheira.

HONZL, J. A mobilidade do signo teatral. Trad: J. Teixeira Coelho Netto In: GUINSBURG, J.; COELHO NETTO, J. T.; CARDOSO, R. C. (Org.) Semiologia do Teatro. São Paulo: Perspectiva, 1978. p. 125-147.

TEATRO DOS SENTIDOS. Teatro dos sentidos. Disponível em: <http://teatrodosentidos.blogspot.com/2009/05/teatro-dos-sentidos.html>

Acesso em: 19 abr. 2019.

VARGAS REYES. E.. Teatro en la oscuridad: Investigación sobre dos experiências argentinas, basada en la teoría teatral de Jorge Dubatti. 155 p. Trabalho final de mestrado - Facultad de Humanidades y Ciencias de la Educación, Universidad Nacional de La Plata. La Plata, 2011. 